DOI: 10.1515/auseur-2016-0014

\title{
Methodological Issues in Monitoring the Hungarian Audiovisual Media in Romania
}

\author{
Rita PLETL \\ Department of Applied Linguistics \\ Sapientia University Tg. Mureş \\ pletlrita@freemail.hu
}

\begin{abstract}
The programme which was planned for more stages started in 2010 and undertook the monitoring of Hungarian news programmes (since 2011, cultural programmes have also been monitored) of national audiovisual media from different regions. The aim of monitoring these programmes is to study the strength of samples as to what extent professional speakers, reporters observe the norms of vernacular language and to what extent their use of language acts as part of sample language in a regional, bilingual, and dialectical environment.

In my study, I present the methodological questions of media monitoring (the aspects of sampling, the requirements regarding content and form in processing documentary material), paying attention to the differences between Romanian and Hungarian media-monitoring programmes.
\end{abstract}

Kewwords: audiovisual media, monitoring, methodology, norms and values in media, regional vernacular language, linguistic fault

\section{Introduction}

My study aims at discussing the methodological issues in monitoring the Hungarian audiovisual media in Romania (aspects of sampling, content and formal requirements in processing the collected documentary material), with special regard to the differences of media monitoring in Romanian and Hungarian. In cases when audiovisual media is broadcasting in regional languages, press monitoring concerned about language use raises a series of methodological questions, as minority media has characteristic features compared to the mainstream just in the linguistic dimension.

In preparing the methodology of monitoring the Hungarian audiovisual media in Romania, a number of factors proved to be crucial. The particularities of minority media had to be taken into account, which basically shaped the sampling procedures, since indicators of mainstream media could not have been fully 
applied. The issue of the Hungarian language's (regional language) status was proven to be an essential factor not only because it limits the potential audience but also because the language sector is important to the Hungarian-speaking community, and this increases the value of the minority media in socialization realized through language. Thus, the complexity of norms had to be taken into account: sample norm, user norm, language and linguistic norm. The status of the Hungarian language in Romania necessitated defining and separating the concepts of vernacular language and regional vernacular language. The active bilingual situation had to be considered an important factor, which favours the frequent occurrence of contactology phenomena, as in the case of language use in a bilingual environment the effect of the majority language is reflected to a certain degree. In processing the collected linguistic material, the greatest challenge was facing the questions regarding 'linguistic misconduct': the problem of respecting and violating the norm, the issue of the adequacy and accuracy of linguistic expressions. Difficult methodological questions were raised by the factors regarding the norm because the methodology used for the Romanian audiovisual media, which served as a template, has clearly and coherently asserted the view that norm should be benchmarked to only a single language version, the literary language. The problem required a solution in two respects. On the one hand, it had to be taken into consideration that the Hungarian sociolinguistic view differs significantly from the Romanian linguistic approach, while, on the other hand, it should have been considered that the different Hungarian linguistic ideologies have different perceptions about the concept of 'linguistic misconduct', 'linguistic error'.

The question referring to the reason why the methodology of Romanian media monitoring was used as template is answered by the background of the examination: the monitoring of the Hungarian audiovisual media was possible only after the National Audiovisual Council of Romania, which performs the tasks of supervising media, extended the examination of language use to the media broadcasting in regional or minority languages.

The examination was preceded by several consecutive events. In 2007, the Romanian Parliament ${ }^{1}$ ratified the European Charter for Regional or Minority Languages (Strasbourg 1992), which sets out general guidelines about the protection of regional or minority languages in the historical Europe in public education and mass media. The legal documents specify that the media authorities of the signatory member states have the duty of protecting minority cultures and languages; where the minority language community exceeds $20 \%$, the media service providers are required to provide a surface for minority broadcasting.

In 2009, Romania has fulfilled its obligation to implement the audiovisual media services directive. The amendment referring to the legal harmonization 
of the audiovisual law adopted in $2002^{2}$ with the European policy was carried out on regulatory level, which was later approved by the Romanian Parliament. The report (Raport 2010), which follows the legal harmonization process and also monitors the practical implementation of directives, was published in 2010. The report provides an objective and authentic picture of the current statutes of media broadcasting in regional language, outlining the shortcomings that should be resolved by the National Audiovisual Council of Romania. In planning our research, we relied on data on Hungarian audiovisual media from the document.

The need for monitoring Hungarian audiovisual media in terms of language use came to the fore when the legal harmonization process with the European directives has been completed in the Romanian legislation. The tasks of the media monitoring institution were completed by the obligations related to national minorities. ${ }^{3}$ Therefore, the protection of regional or minority languages is not only a general principle in the description of the institution's tasks, but the responsibility of media supervising is also assigned. Formulated as an official obligation, it is required to monitor the usage of grammatically flawless language, which respects the existing linguistic norms.

\section{Monitoring the Romanian Audiovisual Media}

The Romanian Academy and the National Audiovisual Council of Romania in 2001 implemented the first monitoring of the Romanian audiovisual media of global nature, based on a national representative sample, focusing on linguistic aspects. The project leaders ${ }^{4}$ highlighted the necessity of media monitoring by pointing out the negative changes resulting from the language use of audiovisual media. Paradoxically, in the 1990s, the possibility of free expression (the enforcement of press freedom) triggered a 'deterioration' of quality in language use because the concept of comprehensibility was misinterpreted. It was the result of an intention to improve audience metrics at all costs, the efforts made to attract listeners and viewers; therefore, the media aimed at addressing itself to everybody. This strategy, however, was not completed by the requirement to produce high-quality linguistic utterances; moreover, the standpoint according to which language use has to comply with existing linguistic standards became less important. This way, the media renounced one of its important roles, namely the cultural and educative function, and the consequences are serious:

$2 \quad$ Legea Audiovizualului nr. 504 din 11 iulie 2002 (Audiovisual Law no 504 of 11 July 2002).

3 The Audiovisual Law stipulates as one of the attributes of the National Audiovisual Council the obligation to ensure the protection of the culture and languages of national minorities, including by pursuing correct usage of these languages (Report 2010,1). 
the number of linguistic and grammatical errors is big, their occurrence is more and more frequent, inaccurate formulation got accepted, familiar language use is gaining ground, trivial expressions appeared in everyday speech, while the frequent occurrence of inadequate utterances for the given communication situation indicates that cultural competence is not effective, it does not help in the formulation of appropriate linguistic manifestations. (The analysis of the monitoring results from 2001 and 2008 was conducted by Gabriela Rusu-Păsărin in the study entitled Limbajul audiovizual între libertate şi calitate [Audiovisual Language Confined within Freedom and Quality].)

The methodological procedures applied in the monitoring from 2001 are the base of the methodology developed for systematic media monitoring.

In 2007, the National Audiovisual Council of Romania started the systematic monitoring of the Romanian audiovisual media, focusing on linguistic aspects. This way, the obligations imposed by the operational regulations were met, as it is required as a priority task that the existing linguistic standards be applied in the mass media communication. The tasks of media monitoring, the professional processing of the collected material have been and are conducted by the researchers of the 'Iorgu Iordan - Al. Rosetti' Institute of Linguistics of the Romanian Academy, and they publish the report about the characteristics of language use in the Romanian audiovisual media every year ${ }^{5}$ and formulate recommendations so that the media can become a guidance source in terms of language use, too.

The methodology of monitoring the Hungarian audiovisual media in Romania discusses aspects of sampling as well as content and formal requirements in processing the collected documentary material. Representativeness was the key aspect of sampling: the national coverage was provided by the selected radio and television broadcasters, public and commercial channels were both selected for sampling. The examined programmes were selected from informative (mostly news), cultural programmes, or from those with educational purposes, considering viewer ratings (programmes with most viewers) as well as the place of the given programme in the programme structure (prime-time broadcasts). The monitoring programme was carried out in a specific time interval, a winterspring and a summer-autumn period.

Not only sounding speaking, but subtitling was examined, too. In the case of sounding speaking, the wider context (communication situation, type of communication, type of discourse) was taken into account as well. Under the programme, the subject to the monitoring was the language use of radio and TV presenters, newsreaders, commentators, and moderators.

In processing the collected material, they followed the linguistic categorizations of the Romanian language, recording the incorrect linguistic expression, while 
also indicating the correct form. (Two books were given as basis of reference: Dicționarul explicativ al limbii române /toate edițiile, Dicționarul ortografic, ortoepic şi morfologic, Bucureşti, 2005.)

They also focus on the language forms, in the case of which linguists do not share the same view, but they do point out in every situation that they follow the rules of literary language. In the case of subtitling, they categorize the errors based on the current Romanian orthography.

The National Audiovisual Council of Romania and the Academy of Sciences of Moldova conducted the monitoring of the Romanian audiovisual media in the Republic of Moldova in 2011. The report on media monitoring (Raport 2011) was published in the same year. From our perspective, this was important because we were hoping that we would find clues in defining 'linguistic misconduct', 'linguistic error' more permissively since in Moldavia a regional version of Romanian is spoken. However, the status of the language differs from the status of the Hungarian in Romania because it is the official language.

According to the report, they applied the same methodology as the one used in the case of Romanian audiovisual media. They point out in the introduction that the features of Romanian literary language should be followed in media, and that it is of prescriptive and compulsory nature. Accordingly, they create different groups for norm violations stemming from regional language use, such as regional variants of words, calques, and loan translations spreading as the result of the Russian language, cases of regional pronunciation and stress. Thus, in examining linguistic phenomena, they implement coherently the traditional view all along, according to which every case of deviation from the standard norm is considered an error, therefore, the regional language forms, too.

\section{Monitoring Hungarian Audiovisual Media in Romania}

The monitoring of Hungarian audiovisual media was initiated by the National Audiovisual Council of Romania, and the implementation of the media monitoring was made possible by the competition of the Media Board of the Communitas Foundation. The monitoring started in 2010 and has become regular in the following years; it was supported by the Hungarian Journalists' Association of Romania, which had a major role in realizing a professional dialogue between the research team of linguists carrying out the media monitoring and the media professionals.

According to the objectives of the programme, the tasks of the professionals conducting the analysis of language use in the audiovisual media are exploring the linguistic peculiarities, preparing the annual report, and formulating recommendations with the aim that the media can become the propagator of demanding, educated language use. 
In preparing the research methodology, the methodology of monitoring the language use of the Romanian media served as an example, but we also had to modify several procedures. We had to take into account the features of Hungarian audiovisual media in Romania. 'The media of Hungarians in Transylvania [...] has the characteristics of the national mainstream media, media markets, and consumer habits, yet, in many respects - financial resources, professionalism and target audience-it is marked by the disadvantages resulting from vulnerability and minority position (2012: 11-12). These characteristics resulted in modifications regarding both the sampling procedure and the processing of the material.

The main concern of the sampling procedure was to ensure the representativeness in our case, too; but we had to ensure the regional coverage instead of the national one because the real situation of the Hungarian audiovisual media could only be reflected this way since the regional differences are shown in the media system, too. The primary target audience of the Hungarian media is the Hungarian-speaking community of Transylvania, people who live in geographically different regions. The number of content-providing institutions in the different regions and counties is in harmony with the number of Hungarians from the counties. Cluj County can be considered an exception, where editorial offices of the media service providers can be found at a higher rate than the ratio of Hungarians would impose (Maksay 2012: 11). Looking at the coverage area of some media, it is obvious that the Hungarian coverage is not complete, and there are significant regional differences in the options of receiving Hungarian broadcasts. The regional coverage was provided by the audiovisual mediums that were chosen for sampling from Timişoara, Cluj-Napoca, Târgu-Mureş, Miercurea Ciuc, Sfântu Gheorghe, Odorheiu Secuiesc, and Bucharest.

Following the principle of representativeness, in the process of preparing the sample, we have taken into account the profile of the given medium: public, commercial, as well as local and regional. Grouping media based on their profile reflects the stratification of the Hungarian media in Transylvania, but it also reveals deficiencies and highlights the regional differences. The report of the National Audiovisual Council of Romania also sees a major deficit in the absence of an independent public radio and TV for the Hungarian-speaking community. ${ }^{6}$ As a result, some of the commercial or regional media take on also public service tasks, realized to different degrees and different standards. In our programmes, we aim at preserving and nurturing the Hungarian identity, while the matter of preserving and nurturing the mother tongue is also emphasized.

6 "There is no public radio station exclusively in Hungarian" (Report, 2010, 11). "Vis-á-vis the text of the Charta and the engagement of Romanian authorities to facilitate the creation of at least one television channel in the Hungarian language, this provision has not yet been met by the public services" (Report 2010, 13). 
In the case of the programmes under examination, we followed the criteria of the Romanian sampling: informative and cultural broadcasts were subject to the monitoring. We only examined news programmes among the informative broadcasts, these forming the larger part of the sample. From 2011, we also included cultural programmes, but we were not able to provide the variety of the Romanian sample. In selecting the programmes, we did not and could not take into account the audience rates or the criteria of broadcasting in primetime because the Hungarian programmes of the Romanian public media have an unfavourable position in the programme structure and the assigned airtime is changing and fragmented as well. Significant differences result from the fact that the Hungarian programmes of the different mediums are aired on a daily or weekly basis and they have different time-frames. This aspect also arises methodological issues in the processing. The major disproportion in the quantity of the sample collected from the different mediums and the different nature of the broadcasts (for example, cultural programmes of different genres) have made it clear that comparing the different broadcasters is not relevant.

The monitoring was conducted in the assigned time interval, the audio and visual material was recorded. The date of sampling changed annually, but the monitoring interval was fourteen days in each of the cases. We were not able to follow the procedure of the Romanian media monitoring regarding the annual sampling in the winter-spring and summer-autumn periods because of the shorter duration of the competition.

In the study of linguistic phenomena, we followed the categories of the system of the Hungarian language: we traced the non-normative phenomena appearing in the given audio recordings on the phonetic, morphological, lexicological, and syntactic level.

In the processing of the recorded material, we followed the methodology of the Romanian media monitoring. The analysis of the materials collected from the media providers was performed by the members of the research group in the following way: the non-normative forms, grammatical errors, linguistic mistakes were recorded, indicating the data regarding the programme (where and when they occurred) and also giving a correct or acceptable form. The analysed materials were then summarized, the non-standard linguistic phenomena were grouped based on the type of violation. The finished report ${ }^{7}$ is in fact a tabulated summary; the columns of the table are constant: they indicate the location of the given form (media provider, date, programme/column, time); the non-normative linguistic form or structure; the recommended standard form; the rows of the table record the non-standard linguistic form; the succession of the tables represents the classification based on the language system.

7 The reports can be found on the sites of the National Audiovisual Council of Romania (20112012) and Sapientia Hungarian University of Transylvania (since 2013). 
The material of the sample was organized based on media types. After processing, it was archived for each year to make tracing the evolution of language use in time possible as well as to aid the researchers to have the complete material in analysing certain linguistic phenomena.

\section{Specific Methodological Solutions}

During regular media monitoring, the methodological procedures became more and more refined. We have not changed the criteria regarding data collection procedures created in the first year, as these provide the representativeness and stratification of the sample; nevertheless, we followed the changes that occurred on the Hungarian language audiovisual market (new media were included in the empirical research, while in the case of others there were significant alterations in the broadcast time).

In the process of media monitoring, we could not exclude the 'official' standpoint that qualifies linguistic phenomena in terms of 'correctness' in such a way that it compares them to the standard norm; in this, we had to fit the requirements of the application.

During the processing of the material, we complied with the basic requirements of the media-monitoring programme (analysing the language use of audiovisual media, outlining the characteristics of language use, preparing the annual report); however, we shifted our focus from the prescriptive approach of the Romanian methodology, which considers the ideal language variety, the standard to be the only norm. We decided upon applying a more descriptive standpoint, which reflects a more flexible approach to norm, taking into consideration the fact of language change and actual language use. According to Lajos Lőrincze: „a nyelvi helyességnek, a normának minden másnál fontosabb meghatározója a szokás, az úzus” (linguistic adequacy, norm is determined foremost by application, usage) (Lőrincze 1973: 267).

The Hungarian linguistic standpoint of a sociolinguistic nature (Gábor Tolcsvai Nagy, Imre Wacha, János Péntek) accepts the existence of several, interdependent norms, and this has proven more appropriate in our analysis of linguistic phenomena collected from Transylvanian media, as we had to study the extent to which the language use of the media fulfils its role as language norm in a regional, dialectal, and bilingual environment. We start from the concept that there are several norms and that they are connected to each other: 'I define media norm as a language variety based on the standard, but richer, more 'elevated' than the language used in everyday communication (...) The centre of ideal media language use is a more 'elevated' media norm based on the standard norm, being in a constant connection with the standard and the artistic norm. The ideal 'internal' norm is the media norm, while its direct 'external' norm is the standard and artistic norm and the external norm not included is group norm' (Balázs 
1998: 91). We constantly followed the basic rule that the normative language variety has to be accepting and not exclusionary regarding the Hungarians living in a minority (Péntek 2001).

While processing the yearly collected linguistic data, we realized the fact that in analysing language use we had to strive to shift our focus from correctness to appropriateness. Consequently, we created a separate group for stylistic problems: the frequent cases when synonymous but stylistically different words were interchanged, the also frequent forms of style blending, the more rare examples for style breaking; we also created a separate group for linguistic phenomena where the violation of grammatical and socio-cultural norms are intertwined. From this point of view, 'linguistic correctness' guides us regarding the community system of values on linguistic utterances.

The linguistic phenomena occurring in one register of the language of the press, the official register were grouped separately, and reflected the impact of the Romanian language on the Hungarian language. This group includes the occurrence of calques, loan translations and hybrid words, the paraphrases related to the lack of competences in special languages, imperfect translations due to the lack of proficiency in the legal language, as well as unacceptable Hungarian equivalents of Romanian names of institutions.

Our research differs from the Romanian in terms of not formulating recommendations. We considered it appropriate to examine the phenomena and issues arising during the processing of the media-monitoring material and to publish our findings in articles and analyses. This was considered to be useful in several respects. The analytical approach can ensure the examination of the observed linguistic phenomena to be embedded in a theoretical framework; it makes possible to be cautious about the research of violations of norm based on our assumption that norm is multilayered. We considered exploring the sociocultural background of audiovisual media significant; we give a thorough examination of linguistic phenomena (e.g. contact phenomena) that are the result of the fact that the Transylvanian regional standard is in a more direct contact with dialects and the official language of the state. We also strived to describe the characteristics of language use in Hungarian audiovisual media in Romania. Based on the collected data, studies have been drawn up on the pronunciation characteristics of minority Hungarian language varieties, on the cases of regular errors in the use of affixes, on analytical structures that are more and more widespread as the result of the effect of foreign languages, on syntactic characteristics, on the frequency of occurrence of elements from the regional standard and sociolects, as well as on characteristics of language use resulting from translation.

We believe that these research documents are more suitable to reflect our intent to raise linguistic awareness and to encourage language use than recommendations. This is why a series was started: in each volume, we group 
the articles around a topic important from the point of view of media monitoring, such as the sociolinguistic status of the Hungarian language in Romania, aspects of language norm, and the culture of mother tongue language use in the Hungarian audiovisual media in Romania.

Unlike the Romanian media monitoring based on the prescriptive approach, we did not focus on finding incorrect forms; applying the descriptive approach, we aimed at outlining prevailing trends and phenomena in language use. So far, the studies present the linguistic situation at a given time, and as such they are reports on the language use of Hungarian media in Romania. After five years of monitoring, the following task that entails new methodological challenges is tracing the changes of certain linguistic phenomena in time.

Our wish is that our media-monitoring research becomes a usable, applicable basis for cooperation with professionals working in the media to think about what language patterns the viewers, listeners hear and see on television and on the radio.

\section{Bibliography}

BALÁZS Géza. 1998. Magyar nyelvkultúra az ezredfordulón. Budapest: A-Z Kiadó.

LŐRINCZE Lajos. 1973. Nyelvszokás és nyelvi norma. Magyar Nyelvốr 69: 266275.

MAKSAY Ágnes. 2012. Az erdélyi magyar média. In: APRÓ István (ed.), Határon túli magyar nyelvú médiumok 2010/2011. Kutatási jelentések. Médiatudományi Intézet, 11-37.

PÉNTEK János. 2001. A nyelv ritkuló légköre. Szociolingvisztikai dolgozatok. Kolozsvár: Komp-Press Kiadó, Korunk Baráti Társaság.

Raport privind implementarea în România a Cartei europene a limbilor regionale sau minoritare, Capitolul Mijloace de comunicare. 2010.

http://www.divers.ro/uploads_ro/37454/10382/RAPORT_CARTA_CAPITOL_ MEDIA_final.pdf.

Raport de monitorizarea a posturilor TV sub aspectul calității limbii române (octombrie-noiembrie 2011).

RUSU-PĂSĂRIN, Gabriela. 2008. Limbajul audiovizual între libertate şi calitate. In: Analele Universității din Craiova - Ştiințe filologice. Lingvistică XXX(12/2008): 247-251.

TOLCSVAI NAGY Gábor. 1996. A magyar nyelv stilisztikája. Budapest: Nemzeti Tankönyvkiadó.

WACHA Imre. 1999. Szöveg és hangzása: cikkek, tanulmányok a beszédról. Magyar Rádió Rt., Budapest. 